\title{
Geoturismo na área de abrangência do COREDE Campanha ('metade sul' do Rio Grande do Sul, Brasil), parte I: geomonumentos de interesse turístico
}

\section{Geoturismo en el area del COREDE Campanha ('mitad sur' del Estado de Rio Grande do Sul, Brasil), parte I: lugares geológicos de interés turístico}

\section{Geotourism in the territory of the COREDE Campanha ('southern-half' of Rio Grande do Sul State, Brazil), part I: geosites of touristic interest}

\author{
André Weissheimer de Borba \\ awborba.geo@gmail.com \\ Universidade Federal de Santa Maria, UFSM, Santa Maria, RS \\ Felipe Guadagnin \\ felipe.guada@yahoo.com.br \\ Universidade Federal do Pampa, Unipampa, Caçapava do Sul, RS \\ Vinícius Matté \\ vinimatte@msn.com \\ Universidade Federal do Pampa, Unipampa, Caçapava do Sul, RS \\ Felipe Caron \\ pati0403@gmail.com \\ Universidade Federal do Rio Grande do Sul, UFRGS, Campus Litoral Norte, Tramandaí, RS \\ Patrícia Freitas Ferreira \\ pati0403@gmail.com \\ Universidade Federal do Pampa, Unipampa, Caçapava do Sul, RS \\ Sissa Kumaira \\ sissakumaira@gmail.com \\ Universidade Federal do Pampa, Unipampa, Caçapava do Sul, RS \\ Renato Pereira Lopes \\ paleonto_furg@yahoo.com.br \\ Universidade Federal de Santa Catarina, UFSC, Florianópolis, SC \\ Jaciele Carine Sell \\ jacics@gmail.com \\ Universidade Federal de SantaMaria, UFSM, Santa Maria, RS
}


Simone Marafiga Degrandi

simonemdgeo@gmail.com

Universidade Federal de Santa Maria, UFSM, Santa Maria, RS

Ana Paula Souza Corrêa

anacorrea.cp@gmail.com

Universidade Federal do Pampa, Unipampa, Caçapava do Sul, RS

Elisângela Lopes da Silva

silva.elislopes@gmail.com

Universidade Federal de Santa Maria, UFSM, Santa Maria, RS

Luiz Paulo Martins e Souza

martinsesouza@gmail.com

Universidade Federal de Santa Maria, UFSM, Santa Maria, RS

Camile Urban

camile.urban@gmail.com

Universidade Federal de Pelotas, UFPel, Pelotas, RS

Adriano Luis Heck Simon

adrianosimon@gmail.com

Universidade Federal de Pelotas, UFPel, Pelotas, RS

Eliseu Balduíno

vicent.lyh@gmail.com

Universidade Federal de Santa Maria, UFSM, Santa Maria, RS

Maurício Rizzatti

geo.mauricio.rizzatti@gmail.com

Universidade Federal de Santa Maria, UFSM, Santa Maria, RS

Resumo: O presente trabalho traz um inventário qualitativo de geomonumentos do tipo 'grandes áreas complexas' na área de abrangência do COREDE Campanha, na chamada 'metade sul' gaúcha. O levantamento considerou mapas geológicos, bibliografia publicada, uso conhecido de locais geopatrimoniais de interesse pela população local, bem como um modelo digital do terreno (MDT), que apontou áreas de grande altitude ou declividade acentuada. Oito geomonumentos foram identificados como de interesse turístico, e são descritos em suas características de geodiversidade, pontos de destaque e atratividade turística, atividades já realizadas e infraestrutura existente. Espera-se que este levantamento estimule os municípios, e especialmente as instâncias de planejamento do COREDE, a considerar o geoturismo uma oportunidade interessante de desenvolvimento socioeconômico sustentável para a região.

Palavras-chave: geodiversidade, geopatrimônio, turismo, inventário, esportes de aventura;

Resumen: Este trabajo presenta un inventario cualitativo de lugares geológicos de interés de tipo 'grandes áreas complejas' en el territorio del COREDE Campanha, en la llamada 'mitad sur' del Estado de Rio Grande do Sul, Brasil. El relevamiento ha 
llevado en cuenta a cartas geológicas, trabajos publicados, utilización ya conocida de estos lugares por la población local, así como un modelo digital de terreno (MDT), el cual ha apuntado áreas de grande altitud o declividad. Ocho lugares geológicos de interés turístico han sido identificadas, y son aquí detalladas en términos de geodiversidad, puntos de destaque como atractivos turísticos, actividades ya realizadas y su infraestructura existente. Se espera que este relevamiento sea un estímulo a que los municipios y especialmente la entidad de planeamiento des COREDE a ver al geoturismo como una oportunidad interesante para el desarrollo social y económico sostenible de la región.

Palabras-clave: geodiversidad, geopatrimonio, turismo, inventario, deportes de aventura;

\begin{abstract}
This paper presents a qualitative inventory of 'complex areas'-type geosites within the territory of the COREDE Campanha, in the so-called 'southern-half' at the State of Rio Grande do Sul, Brazil. The assessment has taken into account published scientific papers and geological maps, known use of geosites by local residents, as well as a digital terrain model (DTM), which has pointed out to some high altitude or steepness areas. We identified eight geosites and provided detailed description in terms of geodiversity, several potential points of tourism, on-going activities, and existing infrastructure. This assessment could be an incentive for the municipalities and especially the COREDE executive board as they could consider geotourism as an interesting opportunity for the social and economic sustainable development in the region.
\end{abstract}

Keywords: geodiversity, geoheritage, tourism, inventory, outdoor sports;

\title{
INTRODUÇÃO
}

O potencial turístico das ocorrências e feições geológico-geomorfológicas e de sua evolução no tempo é um assunto relativamente recente nas geociências. Mesmo que muitos dos mais importantes destinos turísticos do mundo (Grand Canyon do Colorado, Cataratas do Iguaçu ou Niágara, geleira Perito Moreno da Patagônia Argentina, entre muitos outros) apresentem um preponderante viés geológico subjacente, o desenvolvimento de um turismo que promova tais destinos com um olhar além do valor estético é ainda algo bastante incipiente, iniciado somente na década de 1990.

No âmbito da 'geoconservação' (HENRIQUES et al., 2011), todas as feições e elementos geológicos em uma determinada região ou território compõem sua geodiversidade (GRAY, 2004). A fração da geodiversidade que se destaca em função de seus valores estéticos, culturais, utilitários, ecológicos, científicos ou educativos adquire caráter patrimonial e pode ser tratada como patrimônio geológico ou 'geopatrimônio' (BRILHA, 2005; BORBA, 2011; BORBA; SELL, 2018), merecendo iniciativas de valorização e conservação. Por fim, o 'geoturismo' (HOSE, 1995) utiliza os elementos e, sobretudo, os locais componentes do geopatrimônio, chamados de 'geossítios' ou 'geomonumentos', para promover o desenvolvimento local sustentável, de base comunitária, através da visitação (BORBA; SELL, 2018).

Nesse contexto, a presente pesquisa focaliza a geodiversidade e o geopatrimônio da área de abrangência do COREDE Campanha, no âmbito de uma estratégia no sentido de fomentar a ideia de geoturismo para essa região. Os Conselhos Regionais de Desenvolvimento 
(COREDEs) são associações de direito privado, sem fins lucrativos, previstas na Constituição do Estado do Rio Grande do Sul, que têm por objetivos: (a) formular e executar estratégias regionais; (b) estimular a participação cidadã; e (c) difundir a filosofia da cooperação e da busca de parcerias para o desenvolvimento regional (CARGNIN, 2011; BORBA, 2017). No âmbito dos COREDEs, a população é estimulada anualmente a votar suas prioridades em consulta popular. Em 2015, a votação no COREDE Campanha, que reúne sete municípios da 'metade sul' gaúcha (Aceguá, Bagé, Caçapava do Sul, Candiota, Dom Pedrito, Hulha Negra e Lavras do Sul) ${ }^{1}$, elegeu, entre outras, a temática 'geodiversidade e turismo', o que motivou a realização do presente levantamento. Os objetivos deste trabalho, portanto, são a identificação, a avaliação e a apresentação dos geomonumentos passíveis de promoção pelo setor turístico dos sete municípios, no sentido de oferecer o geoturismo como um novo aporte ao desenvolvimento sustentável da região.

Figura 1: Limites administrativos do COREDE Campanha, estado do Rio Grande do Sul.

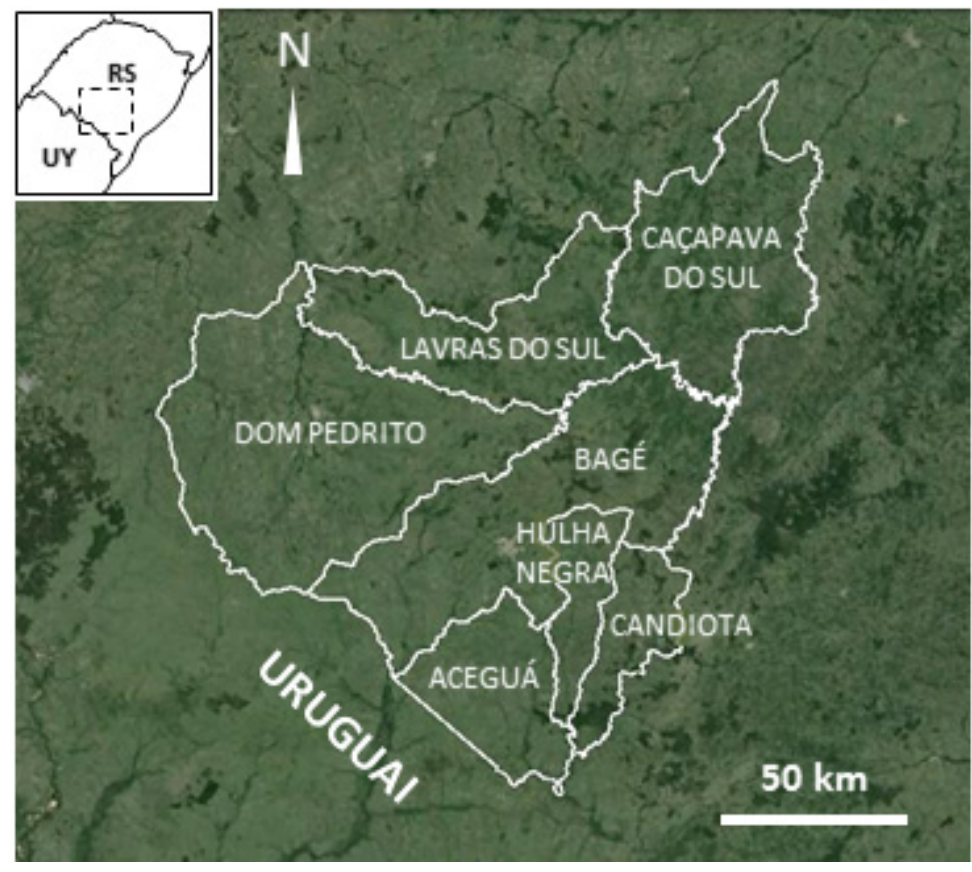

Fonte: os autores.

\section{Geoturismo: conceito, inventário de conteúdos e interpretação geopatrimonial}

O termo 'geoturismo' (geotourism) foi introduzido por Hose (1995, p. 17) para definir " (...) uma estrutura de serviços e interpretação que permita ao turista a aquisição de conhecimento e entendimento sobre a geologia e a geomorfologia de um local (...) além da mera apreciação estética". A intenção era motivar atividades similares às desenvolvidas no ecoturismo, já bem explorada como integração do turismo com as ciências biológicas e a ecologia. Em outro contexto e com outros objetivos, Tourtellot (2006) introduziu uma conceituação diferente, tratando geoturismo como um “ (...) turismo que sustenta e incrementa

1 Juntos, esses sete municípios abrangem um território com mais de $18 \mathrm{Km} 2$. 
o caráter geográfico de um local, de seu meio ambiente, patrimônio, estética, cultura, bem como o bem-estar de seus residentes", em uma clara contraposição ao turismo de massas, dominante naquele momento.

Neste trabalho, não se vislumbra qualquer conflito ou incompatibilidade entre as duas maneiras de se abordar o geoturismo. Portanto, utiliza-se aqui um conceito híbrido, entendendo geoturismo como um turismo sustentável, respeitoso com a cultura e o meio ambiente locais, onde os principais atrativos sejam elementos da geodiversidade e/ou do geopatrimônio. Borba e Sell (2018) reforçam que o geoturismo deve ter as seguintes características: (a) se aproximar de um turismo de base comunitária - TBC (CORIOLANO, 2012), ou seja, integrado socialmente, gerando emprego e renda, priorizando a participação da comunidade local; (b) ser um turismo de conhecimento, por meio da interpretação; e (c) proporcionar uma 'viagem no tempo', permitindo que o turista realmente tenha experiências que lhe dêem uma sensação de ter visitado ambientes (ou mesmo participado de eventos) do passado geológico.

A formatação de atividades, roteiros ou programas de geoturismo passa, necessariamente, por uma etapa inicial de inventário e avaliação qualitativa ou quantitativa dos conteúdos que se quer promover. O inventário, em geral, leva em consideração informações obtidas a partir de: (a) revisão bibliográfica em publicações científicas, jornalísticas ou de promoção por órgãos públicos e privados; (b) modelos digitais do terreno, que indiquem áreas de altitude ou declividade destacada; (c) trabalhos de campo; e (d) uso consagrado para atividades turísticas ou recreativas prévias. Com relação à quantificação, muitos parâmetros podem ser utilizados para uma classificação dos conteúdos. Para Fassoulas et al. (2012), por exemplo, o valor turístico de um geomonumento depende principalmente de seus aspectos estéticos, sobretudo da visibilidade (de um morro ou de uma cascata, por exemplo) e do destaque que apresenta em relação à paisagem do entorno; mas também de aspectos culturais, de potencial de afluxo de visitantes e, ainda, de acessibilidade dos atrativos. Já FuertesGutiérrez e Fernández-Martínez (2010) apontam que geomonumentos com maior extensão (áreas, áreas complexas ou miradores para essas áreas) são os geomonumentos de maior resistência à pressão e de maior potencial de popularização, sendo os mais adequados ao geoturismo. Os trabalhos de Sell (2017) e Sell e Borba (2018) chamam a atenção também para o potencial das estradas e rodovias, especialmente equipadas com miradores, na promoção turística de paisagens e, nessas paisagens, de seus atributos de geodiversidade.

Para proporcionar uma 'viagem no tempo' que envolva diversão, prazer e aquisição de conhecimento, a ferramenta mais empregada no âmbito do geoturismo é a interpretação geopatrimonial. A interpretação é uma atividade educativa/recreativa que envolve contato direto com o objeto ou se utiliza de meios ilustrativos, buscando disponibilizar ao visitante oportunidade de construir um significado e estabelecer vínculos com o tema (TILDEN, 1957). Pode-se dizer ainda, que a interpretação consegue levar o ser humano a compreender seu lugar no ambiente (ALDRIDGE, 1973). Isso se processa, sobretudo, através da tradução da linguagem complexa da natureza em uma linguagem mais acessível, sem perda de significado ou precisão, criando assim sensibilidade, consciência, entusiasmo, entendimento e compromisso com a conservação daquele conteúdo ou ambiente (RISK, 1982). 


\section{O COREDE Campanha e sua geodiversidade}

Do ponto de vista da geodiversidade (geologia e geomorfologia), o COREDE Campanha constitui um território muito rico e diversificado. Posiciona-se, em sua maior parte, na zona mais heterogênea do Escudo Sul-rio-grandense, unidade geológica que encerra algumas das rochas mais antigas do sul do Brasil e que corresponde, na geomorfologia, ao Planalto Sul-rio-grandense ou Serras de Sudeste. Esse contexto ocupa a maior parte dos municípios de Caçapava do Sul, Lavras do Sul, Dom Pedrito e Bagé. Ali ocorrem: (a) rochas metamórficas e ígneas de mais de 2 bilhões de anos de idade e associadas a um contexto cratônico; (b) rochas metavulcânicas e metassedimentares do Neoproterozoico, depositadas e metamorfizadas entre 1 bilhão e $600 \mathrm{Ma}$ (milhões de anos atrás), em ambientes diversos; (c) rochas vulcânicas e sedimentares da chamada Bacia do Camaquã, depositadas entre 630 e $500 \mathrm{Ma}$, compreendendo arenitos, conglomerados, siltitos, riolitos, andesitos e basaltos; e (d) corpos isolados de granitoides cujo posicionamento se processou também entre 600 e $500 \mathrm{Ma}$ (BORBA et al., 2013).

O conjunto de rochas detalhado acima, formado em sua maioria em grande profundidade, foi sendo soerguido de maneira diferencial ao longo do Fanerozoico e, a partir da erosão das camadas superiores, progressivamente exposto à superfície. Diante da variedade de tipos litológicos e da justaposição de blocos limitados por estruturas tectônicas, a resposta desse conjunto aos fatores climáticos e ao intemperismo foi muito variada, levando à formação de um relevo tão diversificado quanto a litologia: serras e vales alongados segundo as direções preferenciais da tectônica regional (NE-SW e NW$\mathrm{SE}$ ), cerros graníticos com extensos campos de matacões, cristas e hogbacks de quartzito, elevações isoladas de grande destaque na paisagem, além dos cerros tabulares e relevos ruiniformes das áreas adjacentes ao rio Camaquã. Essa diversidade de elementos abióticos também foi determinante para a diversidade de ecossistemas e paisagens dessa área, que Sell (2017) denominou 'pampa serrano'. Caçapava do Sul é o município que sintetiza, mais que qualquer outro, toda essa variedade natural de elementos da geologia e da geomorfologia, fato que ensejou seu reconhecimento, por lei, como Capital gaúcha da geodiversidade (Lei Ordinária Estadual 14.708, de 15 de julho de 2015).

Outra porção importante do território do COREDE Campanha está posicionada no setor sul do compartimento geomorfológico denominado Depressão Periférica ou Depressão Central. Seu substrato geológico é formado por rochas sedimentares da Bacia do Paraná, depositadas ao longo do período Permiano (290 a 250 Ma). São arenitos, siltitos, argilitos e carvões, que dominam o subsolo na porção sul dos municípios de Bagé e Dom Pedrito, e na quase totalidade dos municípios de Aceguá, Candiota e Hulha Negra. Por serem rochas de natureza sedimentar dominantemente finas, muito friáveis e pouco resistentes ao intemperismo físico e químico, sua presença deu origem a uma geomorfologia plana a levemente ondulada. Esse relevo de coxilhas corresponde ao pampa mais presente no imaginário coletivo dos gaúchos - o 'pampa ondulado' do trabalho de Sell (2017), onde as grandes estâncias e os rebanhos de gado bovino ainda constituem os traços mais marcantes da paisagem. 


\section{METODOLOGIA $^{2}$}

Uma etapa permanente da pesquisa foi a consulta a artigos científicos, monografias, dissertações e teses que se propuseram a levantar e inventariar a geodiversidade e o geopatrimônio dos municípios da área de estudo. Trabalhos fundamentais nesse sentido, em áreas de diferente abrangência territorial, foram publicados por Degrandi (2011), Borba et al. (2013), Peixoto (2017) e Sell (2017). Também foram buscados e consultados trabalhos versando sobre geomonumentos ou elementos geopatrimoniais específicos (PAIM; FALLGATER; SILVEIRA, 2010; DOMINGUES, 2016; SANTOS, 2016; SILVA, 2016; BORBA et al., 2016; ISMÉRIO et al., 2017).

Outra etapa metodológica desta pesquisa foi a construção de mapas hipsométrico (altitudes) e clinográfico (declividades) da área de abrangência do COREDE Campanha. Para a confecção do mapa hipsométrico, adquiriram-se no Earth Explorer imagens SRTM (Shuttle Radar Topography Mission) que cobriram totalmente a área de estudo, com resolução espacial de 30 metros, servindo como Modelo Digital do Terreno (MDT). O modelo digital foi reprojetado para coordenadas planas - Sistema Universal Transverso de Mercator (UTM). Pelo fato dos limites da área de estudo se estenderem por dois fusos UTM, os mapas foram gerados de maneira separadas (por fusos) e posteriormente transformados para o Sistema de Referência Geocêntrico para as Américas (SIRGAS 2000), unidos por mosaicagem.

Para uma representação cartográfica discreta, isto é, por classes altimétricas, realizou-se uma reclassificação do MDT por meio da ferramenta r.recode. Os limites dos municípios foram adquiridos no acervo do portal virtual do Instituto Brasileiro de Geografia e Estatística (IBGE) e as rodovias e rede de drenagem da Base Vetorial Contínua do Rio Grande do Sul (HASENACK; WEBER, 2010). O mapa foi finalizado no compositor de impressão do software livre QGIS 2.18.

O mapa de declividade foi gerado a partir da aplicação de uma fórmula matemática, obtida através da relação existente entre altura (distância vertical) entre dois pontos e sua respectiva distância no plano. Para sua confecção no QGIS, utilizou-se o algoritmo r.slope (ferramenta do GRASS GIS), com o mesmo MDT do mapa hipsométrico. Para a sua organização em intervalos de classes, utilizou a metodologia e as razões propostas por De Biasi (1992, p. 47):

$<5 \%$ - Limite urbano industrial, utilizado internacionalmente, bem como em trabalhos de planejamento urbano efetuados pelo Instituto de Pesquisas Tecnológicas do estado de São Paulo.

5-12\% - Este limite possui algumas variações quanto ao máximo a ser estabelecido (12\%), pois alguns autores adotam as cifras de $10 \%$ e/ ou $13 \%$. A diferença é muito pequena, pois esta faixa define o limite máximo do emprego da mecanização da agricultura.

12-30\% - O limite de 30\% é definido por legislação Federal - Lei 6766/79 - que define o limite máximo para urbanização sem restrições.

2 Apoiado pela Fundação de Amparo à Pesquisa do Estado do Rio Grande do Sul (FAPERGS), através do projeto 16/25510000383-1, contemplado no Edital Fapergs Pró-COREDE Campanha. 
30-47\% - O Código Florestal, fixa o limite de $25^{\circ}$ (47\%), como limite máximo de corte raso, a partir do qual a exploração só será permitida se sustentada por cobertura de florestas.

$>47 \%$ - O artigo 10 do Código Florestal prevê que na faixa situada entre $25^{\circ}(47 \%)$ a 45 o $(100 \%)$, "não é permitida a derrubada de florestas, [...] sendo tolerada apenas a extração de toras, quando em regime de utilização racional, que vise a rendimentos permanentes" (DE BIASI, 1992, p. 47).

Para reclassificar o raster de declividade gerado para apresentar o intervalo de classes apresentados acima, utilizou-se a ferramenta r.recode. A finalização do mapa deu-se no compositor de impressão do QGIS, com uso da variável visual cor com implantação zonal. Os mapas hipsométrico e clinográfico foram utilizados para a identificação de 'áreas-alvo', de significativa amplitude altimétrica e/ou de substancial declividade, que em geral são candidatas a apresentar uma geodiversidade intrínseca muito grande, além de um apelo visual e cênico importante, correspondendo a áreas de potencial atratividade turística.

Consultas a sítios eletrônicos da internet, de entidades públicas ou privadas, relacionados aos sete municípios do COREDE Campanha, possibilitaram identificar usos turísticos ou recreativos de elementos relevantes da geodiversidade. Por fim, de posse dos dados da literatura, dos mapas hipsométrico e clinográfico, bem como das informações de publicações eletrônicas, foram realizadas saídas a campo no sentido de avaliar qualitativamente os potenciais geomonumentos e sua representatividade na escala e área de abrangência do COREDE Campanha. Nesta etapa, esses elementos geopatrimoniais foram fotografados e filmados, tanto com câmeras fotográficas digitais quanto com drone da marca DJI, modelo Phantom 4 Pro. Considerando que o geopatrimônio não se compõe apenas de locais geológicos materializados na superfície, mas também de elementos geopatrimoniais ex situ (como fósseis, por exemplo), além de contextos e identidades, esses últimos também recebem atenção especial em um artigo específico (BORBA et al., parte II, neste número).

\section{RESULTADOS E DISCUSSÃO}

\section{Altitude e declividade}

Os mapas hipsométrico (Fig. 2) e clinográfico (Fig. 3) do território de abrangência do COREDE Campanha revelaram, conforme mencionado anteriormente, duas áreas distintas, separadas por uma linha imaginária curva, de direção NW-SE, que acompanha a rodovia BR-293 desde o limite leste do território, infletindo para N-S já nas proximidades da zona urbana de Dom Pedrito. Essa linha efetivamente separa um domínio sedimentar a sul-sudoeste, relativamente homogêneo e de relevo suave, representado pelas rochas da Bacia do Paraná, de um domínio cristalino, heterogêneo e de relevo mais movimentado, com declividades mais altas (e, localmente, muito altas) a norte-nordeste, cujo substrato é composto pelas rochas ígneas, metamórficas e sedimentares antigas do Escudo Sul-rio-grandense. 
Levando em consideração a altitude, apenas três áreas se destacam, posicionando-se acima de 300 metros, com alguns pontos mais altos do que 400 metros: (a) o alto topográfico onde se situa a área urbana de Caçapava do Sul (ponto 1 na Fig. 2), formado por granitoides cortados por estruturas tectônicas de direção NW-SE; (b) o alto topográfico da zona de Acampamento Velho (ponto 2 da Fig. 2), na terminação leste do 'platô da Ramada', no extremo norte do município de Lavras do Sul, formado predominantemente por rochas vulcânicas de composição ácida, como riolitos, tufos e ignimbritos; e (c) o amplo alto topográfico da região de Meia-Lua ou Lagoa da Meia-Lua (ponto 3 da Fig. 2), centro-norte do município de Lavras do Sul, nos domínios do granito Jaguari, especialmente em suas porções sienograníticas.

Figura 2: Mapa hipsométrico do COREDE Campanha, com limites dos municípios, rodovias e áreas urbanas localizadas, indicando as áreas-alvo: (1) alto topográfico de Caçapava do Sul; (2) zona de Acampamento Velho; (3) Lagoa da Meia-Lua; as duas últimas situadas no município de Lavras do Sul.

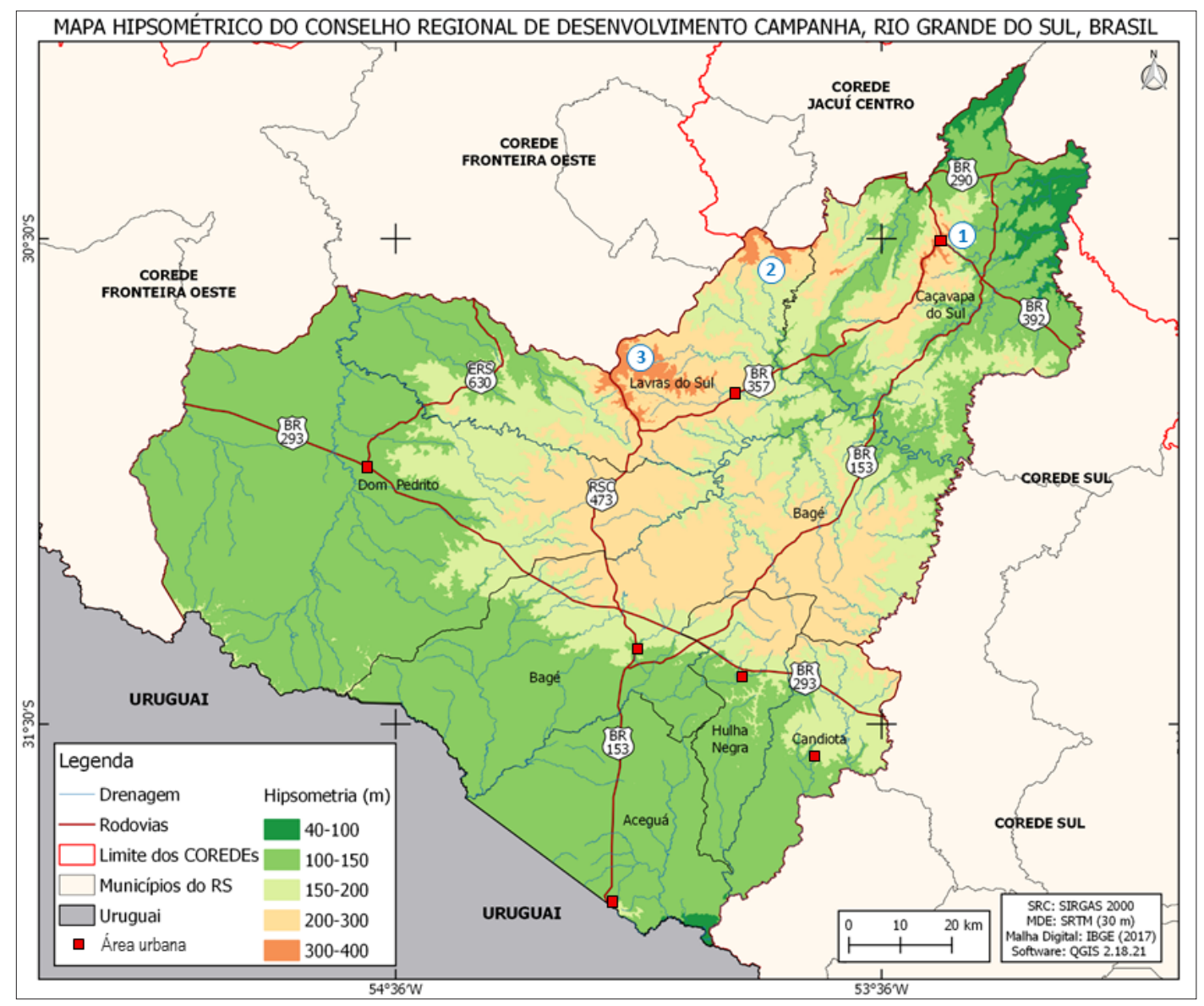

Fonte: os autores.

Considerando o mapa de declividades (Fig. 3), a setorização do COREDE Campanha em duas porções distintas se mantém, com planícies e áreas de relevo coxilhado suave a sul-sudoeste, e maiores declividades a norte-nordeste, incluindo um predomínio de áreas com declividade entre 12 e 30\% em Caçapava do Sul, leste de Lavras do Sul e norte de Bagé. Uma série de áreas-alvo de potencial geopatrimônio foram identificadas, tendo 
sua localização ilustrada na Figura 3. São áreas com registro, no MDT, de porções com declividades entre 30 e $47 \%$ e que, localmente, apresentam paredões com declividades ainda maiores do que $47 \%$. Propositalmente, iniciou-se a numeração nesta nova figura pelo número 4, para não sobrepor com os locais apresentados na Figura 2.

O município de Caçapava do Sul possui três dessas áreas-alvo: (a) a Serra de Santa Bárbara, especialmente nas imediações dos cerros do Bugio e Perau e da Cascata do Pessegueiro (ponto 4 da Fig. 3), formada por rochas vulcânicas ácidas; (b) a Serra do Segredo (ponto 5), composta por rochas sedimentares (conglomerados e, subordinadamente, arenitos) que acabam formam um maciço resistente ao intemperismo; e (c) a área das Pedras das Guaritas (ponto 6), geomonumento de maior destaque dentro do município, e também formado por rochas sedimentares (neste caso, arenitos e, subordinadamente, arenitos com seixos e blocos arredondados).

No limite entre os municípios de Bagé e Lavras do Sul, está o Rincão do Inferno (ponto 7 na Fig. 3), área na qual o rio Camaquã aproveita uma importante estrutura tectônica orientada a NE-SW para cruzar um maciço de conglomerados e arenitos muito resistentes. Ainda no norte de Bagé, no distrito de Palmas, está a área da Casa de Pedra (ponto 8), também conhecida como Galpão de Pedra ou Pico do Morcego, formada por conglomerados de origem aluvial. Uma extensa área de relevo muito movimentado, com declividades localmente muito altas, margeia os arroios Torrinhas e Velhaco (ponto 9), já no limite leste do município de Bagé e do COREDE Campanha, na divisa com Pinheiro Machado, constituindo as chamadas Pedras das Torrinhas, também de origem sedimentar antiga.

Já no município de Lavras do Sul, a zona da Meia-Lua, na divisa com São Gabriel, também se destaca no mapa clinográfico, mas em um setor um pouco diferente (ponto 10 da Fig. 3) daquele destacado no mapa de altitudes. No setor oeste da área de abrangência do COREDE Campanha, merecem destaque as altas declividades das bordas do platô do Taquarembó (ponto 11), entre Dom Pedrito e Lavras do Sul, alto topográfico formado principalmente por rochas vulcânicas ácidas (riolitos e ignimbritos). Por fim, já nos domínios de planícies da porção sul de Bagé, um alto topográfico com bordas de declividade relativamente alta, conhecido e registrado em cartas topográficas como Coxilha do Chapadão (ponto 12 da Fig. 3), mereceu atenção preliminar deste inventário após a elaboração do MDT. Porém, seu relativo isolamento, pouca representatividade em área e, sobretudo, a virtual ausência de referências científicas sobre sua geodiversidade, ensejaram sua desconsideração enquanto potencial atrativo geoturístico. 
Figura 3: Mapa clinográfico da área do COREDE Campanha, com limites dos municípios, rodovias e áreas urbanas localizadas.1-11: áreas de destaque em termos de declividade, com potencial para geomonumentos; o ponto 12 não apresentou este potencial.

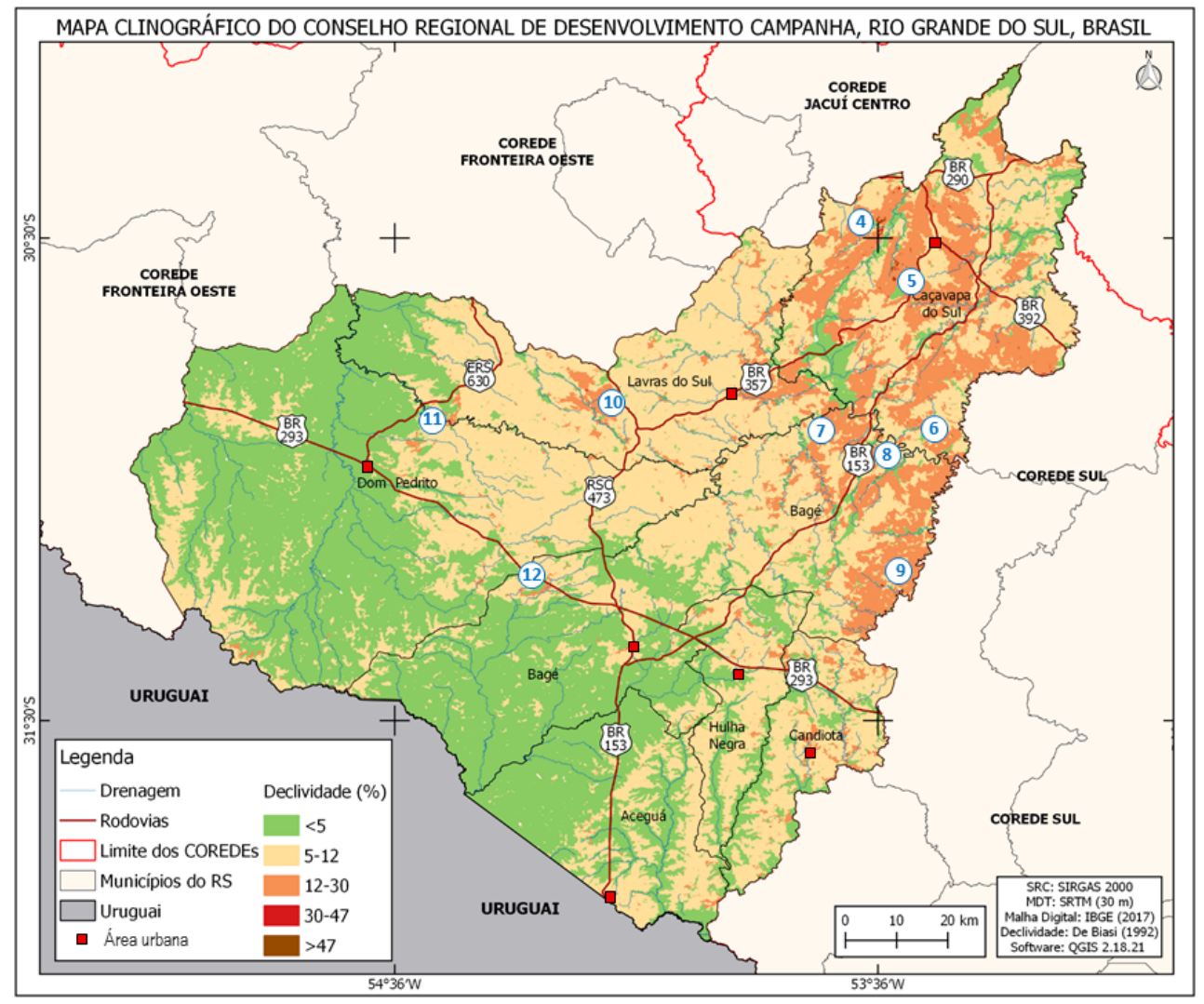

Fonte: os autores.

\section{Geomonumentos}

Considerando a escala de trabalho e a grande área de abrangência do COREDE Campanha, com mais de 18 mil $\mathrm{Km}^{2}$, foram selecionados como geomonumentos apenas aqueles elementos geopatrimoniais do tipo 'grandes áreas complexas' (FUERTESGUTIÉRREZ; FERNÁNDEZ-MARTÍNEZ, 2010), especialmente de forte apelo estético e visual, onde podem ser realizadas uma série de atividades, incluindo, além do geoturismo, a contemplação, o lazer e a prática de esportes de aventura. Esses geomonumentos estão descritos em detalhe na sequência do trabalho. Quando pertinente, são indicados, dentro (ou nas imediações) dessas 'grandes áreas complexas', pontos de maior relevância que poderão ser objeto de maior detalhamento ou de iniciativas mais imediatas de divulgação e interpretação. Por razões de infraestrutura ou acessibilidade, alguns geomonumentos foram priorizados em detrimento de outros com conteúdo semelhante, e os motivos para tal escolha também serão detalhados a seguir. Para permitir um acompanhamento mais adequado por parte do leitor, será utilizada uma ordem que parte do norte em direção ao sul da área de abrangência do COREDE Campanha. 
O alto topográfico onde se situa a zona urbana de Caçapava do Sul (ponto 1 na Fig. 2) possui uma importância central para o geoturismo no COREDE Campanha. O principal motivo é sua localização, que faz com que seja a 'porta de entrada' para os potenciais turistas procedentes de Porto Alegre e região metropolitana, de Santa Maria e região norte do Estado, assim como para os argentinos que trafegam nos meses de verão pela BR-290 em direção aos litorais gaúcho e catarinense. Formado por granitoides diversos, incluindo termos muito ricos em sílica e, por isso, muito resistentes ao intemperismo, esse alto compõe-se de cerros isolados e serras alongadas, delimitadas por estruturas tectônicas. Sobretudo sua porção norte apresenta grande destaque na paisagem, principalmente por estar cercado por rochas metamórficas, muitas com baixa resistência ao intemperismo, que formam vales e abrigam cursos d'água. Sua influência sobre a implantação da própria zona urbana e sobre aspectos culturais do município já foi discutida por Borba, Sell e Figueiró (2014). A área mais interessante, do ponto de vista da conservação ambiental, bem como da possibilidade de contemplação e execução de trilhas na natureza (caminhada e trekking), é o chamado Cerro do Perau (Fig. 4A), a $7 \mathrm{Km}$ da cidade, facilmente acessível por rodovia asfaltada (BR-392). Grandes matacões de granito (Fig. 4B) são as formas mais comuns, e uma queda d'água de substancial beleza cênica (Fig. 4C) completa o potencial atrativo. Esse ponto, no entanto, ainda não possui infraestrutura apropriada para a recepção de visitantes, nem mesmo demarcação de trilhas.

Já em um contexto mais urbanizado, a Vila do Frigorífico, com acesso fácil por estrada não pavimentada desde o campus da Universidade Federal do Pampa (UNIPAMPA), dá uma ideia de como os matacões de granito estão inseridos no cotidiano das pessoas, pois esses elementos da geodiversidade compõem os pátios das casas e são um elemento predominante na paisagem (Fig. 4D). No entanto, ainda não há infraestrutura que garanta uma visita adequada, e qualquer ideia de aproveitamento turístico deverá ser precedida de um contato com os moradores, para consulta sobre seu interesse no assunto. A sul da área urbana, com acesso finalmente recuperado em 2018, após muitos anos de abandono (Fig. 4E), está a Cascata do Salso, queda d'água de cerca de 30 metros de altura (Fig. 4F), que já teve um aproveitamento para geração de energia, mas que hoje se encontra em vias de aproveitamento como balneário e espaço de lazer no verão. No mesmo contexto geológico, e também muito frequentada por banhistas, está a Cachoeira da Pedra Branca, uma sequência de inúmeras quedas d'agua em um trecho de aproximadamente 200 metros. $\mathrm{O}$ que mais chama a atenção para este ponto é a proximidade com a área urbana de Caçapava do Sul, de apenas $2 \mathrm{Km}$ de trajeto pela estrada vicinal conhecida localmente como 'estrada da EMEC', que pode ser acessada via BR-392. Ao final da trilha, há um mirante natural para a cidade de Caçapava do Sul, fator que também pode ensejar um aproveitamento desse ponto, pelo menos para estratégias em âmbito municipal.

Por fim, na área central da cidade, o contexto desse alto topográfico granítico pode ser explorado em uma visita ao Forte Dom Pedro II, cujas muralhas do século XIX foram construídas com blocos cortados e matacões inteiros, arredondados, do granito das 
imediações (Fig. 4G, 4H). Ainda que não seja propriamente um atrativo geoturístico sensu stricto, a fortaleza possui elementos geopatrimoniais que ensejam e merecem interpretação, conforme discutido por Borba et al. (2013; 2014). Sugere-se, por sua posição central, como área de interesse de muitos visitantes, e por ser usada também como área de passagem pela população local no trajeto entre o centro e os bairros do norte da cidade, onde um painel interpretativo sobre esse contexto poderia ser instalado junto às muralhas.

Figura 4: Aspectos do potencial geoturístico do alto de Caçapava: (A) vista panorâmica do Cerro do Perau; (B) matacões arredondados de granito; (C) queda d'água de substancial beleza cênica; (D) matacões graníticos na Vila do Frigorífico; (E) estrada de acesso à Cascata do Salso; (F) Cascata do Salso; (G, H) matacões graníticos arredondados nas muralhas do Forte Dom Pedro II.

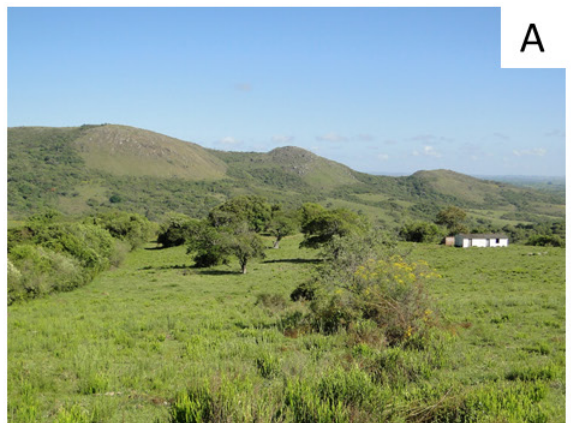

A

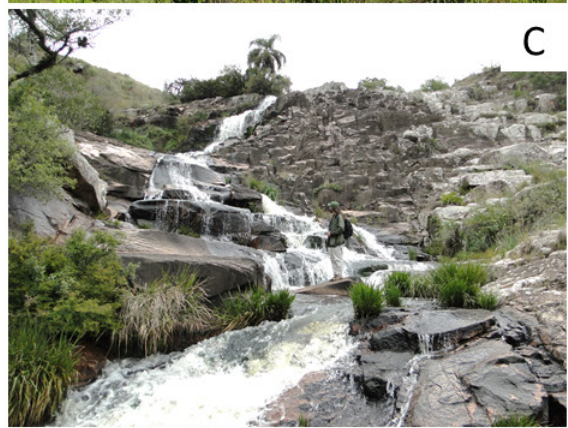

C
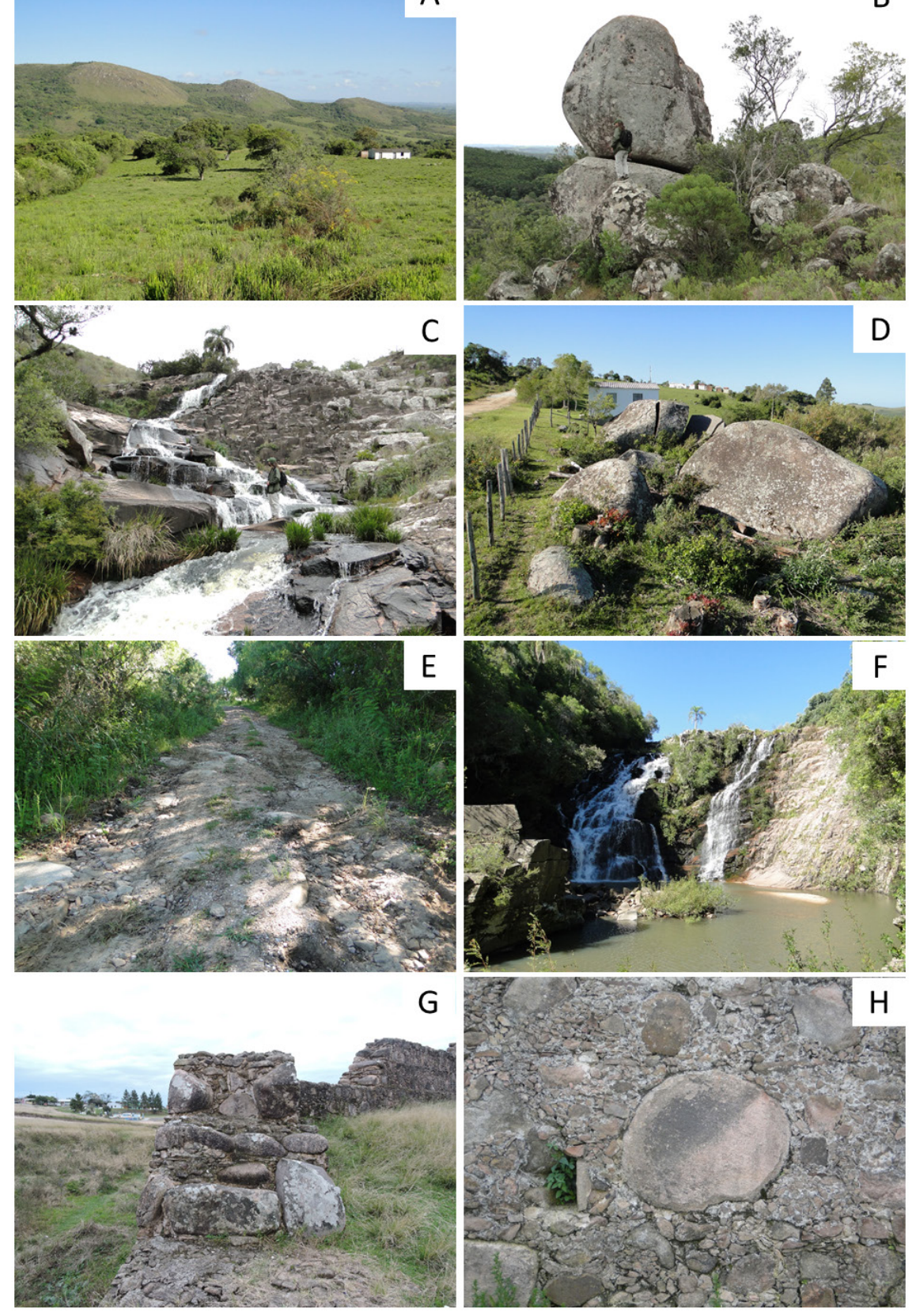

Fonte: fotos obtidas pelos autores. 


\section{Serra de Santa Bárbara}

A Serra de Santa Bárbara (ponto 4 na Fig. 3), chamada também entre os habitantes locais de Cordilheira do Santa Bárbara (Fig. 5A), é um alto topográfico alongado, orientado na direção NE-SW, que se estende por quase $40 \mathrm{Km}$ e constitui o elemento geopatrimonial mais importante da região oeste do município de Caçapava do Sul. É formada por rochas vulcânicas ácidas, também muito ricas em sílica, sobretudo riolitos e ignimbritos, resultantes de erupções e explosões vulcânicas ocorridas há cerca de 570 MA (ALMEIDA et al., 2005).

Os terrenos adjacentes a essa serra são formados por rochas sedimentares marinhas (unidade Maricá) a oeste, e continentais (unidade Santa Bárbara) a leste, todas com granulometria muito mais fina e algum teor de argilominerais. Isso faz com que o comportamento dessas rochas frente ao intemperismo seja totalmente diferente, levando a uma denudação substancial, o que promove um significativo destaque do maciço de rochas vulcânicas na paisagem. Seu potencial para o geoturismo está principalmente ligado aos esportes de aventura, especialmente o voo livre e a caminhada/trekking. Dois pontos muito utilizados para decolagens de asa-delta e paraglider estão nessa serra: o Cerro do Bugio (Fig. 5B) e a Fazenda Guaporã, mais a sul, onde já há obras de estruturação de uma base para eventos de voo livre. Por fim, um terceiro atrativo na Serra de Santa Bárbara é a Cascata do Pessegueiro (Fig. 5C), uma queda d'água relativamente pequena, mas frequentada no verão pela população das imediações. Na Cascata do Pessegueiro encontram-se as melhores exposições das rochas vulcânicas que formam a Serra de Santa Bárbara, especialmente os riolitos com estruturas de fluxo retorcidas e dobradas.

A Serra de Santa Bárbara, por sua relativa proximidade com Caçapava do Sul (15 km) e acessibilidade por duas opções de estradas vicinais (pela estrada 'das catacumbas' ou pela estrada do Segredo, ambas não pavimentadas), apresenta vantagens numa estratégia turística do COREDE Campanha sobre a região do Acampamento Velho ou platô da Ramada (ponto 2 da Fig. 2), já nos limites do território, de mesma constituição e mesma origem geológica. Também contribui para com a seleção da Serra de Santa Bárbara seu maior aproveitamento para o voo livre, bastante consolidado. Outro fator importante é que a rodovia federal BR-290, principal via de ligação entre a fronteira oeste e a capital do Estado, e rota de muitos turistas da região do Prata em direção ao litoral sul-brasileiro, cruza a Serra de Santa Bárbara, tendo inclusive potenciais miradores (mirantes, belvederes) para a contemplação e interpretação dessa paisagem. Assim, sugere-se para o futuro uma gestão junto ao Departamento Nacional de Infraestrutura de Transportes (DNIT), que tem a titularidade sobre as rodovias federais e suas faixas de domínio, para construção de um mirador na BR-290, com os devidos recuos e estacionamento. Espera-se que os condutores, ao contemplar a paisagem, recebam informações e um convite a visitar o COREDE Campanha. Ainda, por seu relativo isolamento e acesso por outras vias e outros municípios que não os contemplados no território analisado, a despeito de seu destaque enquanto alto topográfico, este trabalho irá desconsiderar a área do Acampamento Velho como um potencial geomonumento, priorizando a Serra de Santa Bárbara. 
Figura 5: Atrativos geoturísticos na Serra de Santa Bárbara, em Caçapava do Sul: (A) visão geral da Serra de Santa Bárbara; (B) Cerro do Bugio, ponto de decolagem de voo livre; (C) Cascata do Pessegueiro, no arroio de mesmo nome, com o Cerro do Bugio ao fundo.

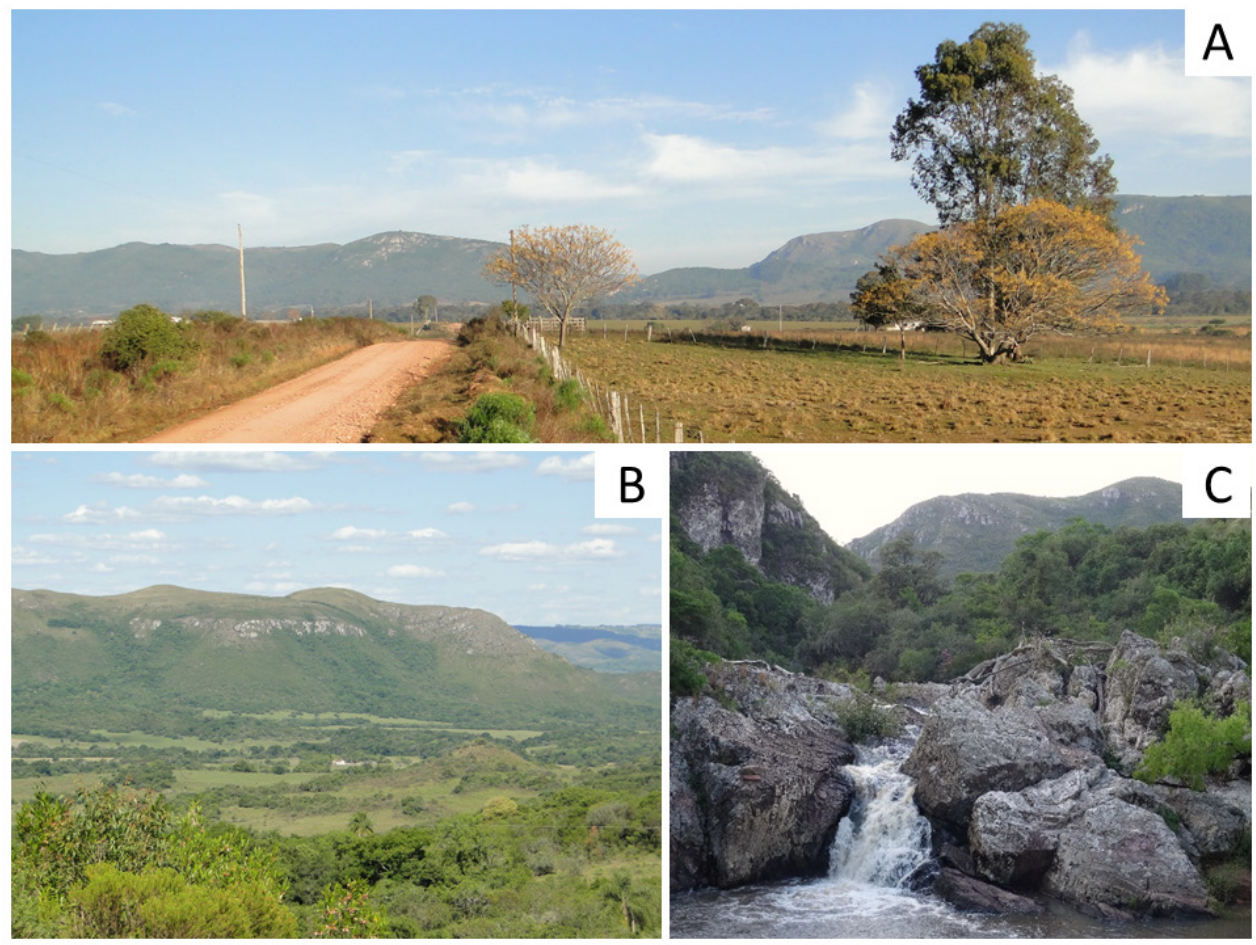

Fontes: fotos obtidas pelos autores.

\section{Serra do Segredo}

A Serra do Segredo, em parte também conhecida como Serra dos Lanceiros, constitui-se de uma área de cerca de 30 km² (BORBA et al., 2016), muito próxima à zona urbana de Caçapava do Sul (ponto 5 da Fig. 3), onde ocorrem cerros ruiniformes de características arredondadas, mas com paredões verticais (Fig. 6A), desenvolvidos sobre conglomerados e arenitos conglomeráticos da unidade Santa Bárbara, de cerca de $550 \mathrm{Ma}$. O trecho de estrada não pavimentada, iniciando-se na RS-357, é relativamente curto (entre 3,5 e 7 $\mathrm{km}$ ), ainda que seja um acesso declivoso, pedregoso e suscetível a erosão. Melhorias na estrada de acesso, incluindo disciplinamento da drenagem, galerias, pontilhões e miradores, poderiam tornar esse geomonumento um dos mais interessantes do Estado, e um dos principais atrativos geoturísticos do COREDE Campanha.

Assim como para outros locais, os principais públicos desse geomonumento estão vinculados aos esportes de aventura na natureza, sobretudo a escalada em rocha (Fig. 6B). São centenas de vias de escalada, muitas delas de grande dificuldade (graus 8 e 9 no sistema brasileiro de graduação de vias de escalada) em diversas geoformas da serra. Caminhada e trekking, expedições fotográficas, observação de aves e observação de cactos (Fig. 6C) são igualmente atividades de grande potencial nessa área (SILVA, 2016). Os dois principais empreendimentos turísticos da Serra do Segredo já são dedicados a essa vocação: (a) o 
camping Galpão de Pedra, muito bem estruturado, em propriedade particular, cuja principal geoforma é a Pedra do Leão; e (b) o Parque Municipal da Pedra do Segredo, espaço de lazer concedido para exploração a uma empresa privada.

A Serra do Segredo também abrange, em sua maior parte, as nascentes do arroio dos Lanceiros, afluente do arroio Santa Bárbara. Tanto a leste quanto a oeste, o maciço de conglomerados é circundado por rochas sedimentares mais finas, como arenitos e siltitos micáceos, e esse também é um fator que empresta ao alto topográfico um substancial destaque na paisagem. No sentido de se aproveitar esse valor estético e cênico, recomenda-se a implantação de miradores de observação e interpretação do relevo e da paisagem, tanto na terminação oeste da Serra do Segredo, para visadas ao fim da tarde, quanto na RS-357 (estrada Caçapava-Lavras), rodovia asfaltada, para visadas de leste para oeste pela manhã. Esse último poderá, inclusive, ser um elemento importante na futura atração de turistas e na conectividade para outros conteúdos no município de Lavras do Sul.

Figura 6: Aspectos geoturísticos da Serra do Segredo, em Caçapava do Sul: (A) Pedra do Segredo e Pedra da Abelha, geoformas arredondadas e de paredes verticais; (B) escalada em rocha; (C) cactáceas do gênero Parodia $s p$ nos paredões.
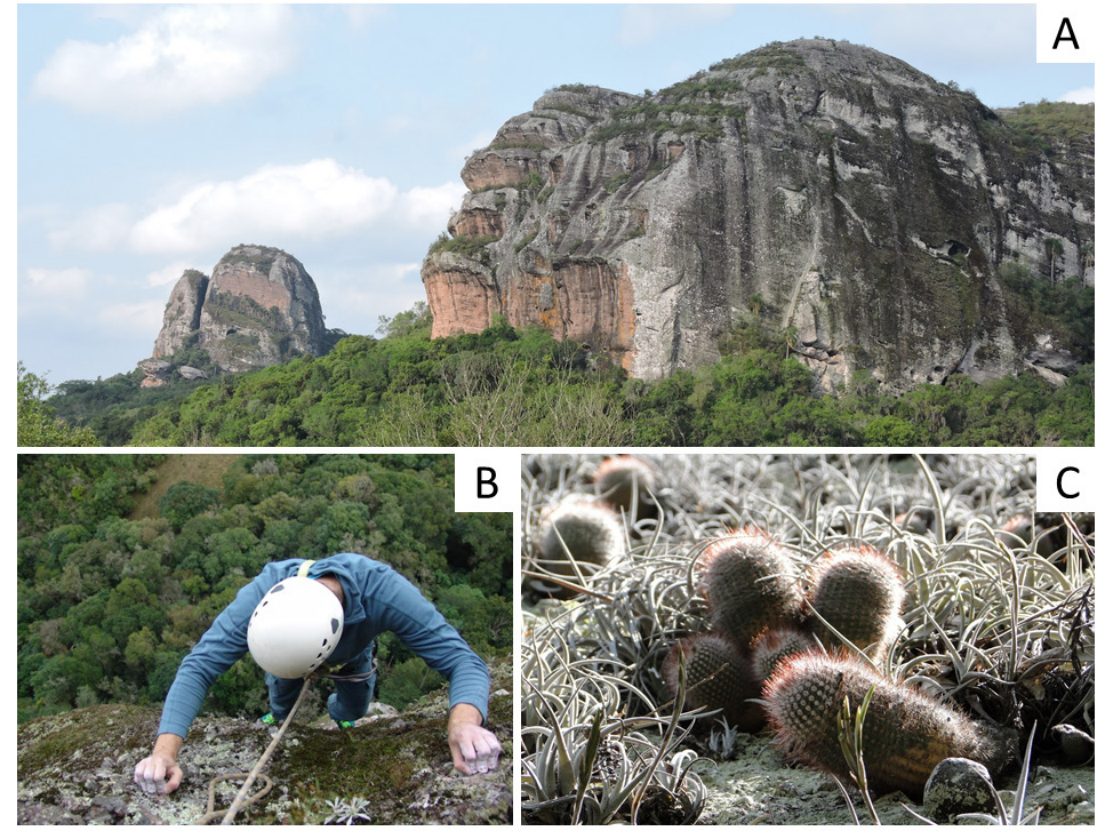

Fonte: (A, C) fotos obtidas pelos autores; (B) foto obtida por Cassiano Lisboa.

Área da Meia-Lua/Palma

A área conhecida como Lagoa da Meia-Lua, Meia-Lua ou Palma, todas toponímias constantes das cartas topográficas do Exército ou de mapas geológicos da área, fica na divisa de Lavras do Sul com São Gabriel, já no limite norte do COREDE Campanha. Constitui-se de um alto topográfico amplo, de mais de $100 \mathrm{~km} 2$, com cota superior a 300 metros (ponto 3 da Fig. 2) e declividades destacadas (ponto 10 da Fig. 3), onde aflora o Granito Jaguari (SOLIANI JUNIOR, 1986; GASTAL; LAFON, 1998), um corpo formado por 
monzogranitos e sienogranitos. Esses últimos, mais ricos em sílica, são os que adquirem maior destaque na paisagem, por sua resistência ao intemperismo, formando lajeados recobertos por matacões (Fig. 7A). Esses matacões possuem dimensões métricas, de forma a se tornar um atrativo importante para praticantes da modalidade de escalada conhecida como bouldering, na qual o objetivo é subir um trajeto curto que oferece nível de dificuldade alto a muito alto. Um conteúdo interessante sobre esse corpo granítico é a ação da Falha Cerro dos Cabritos, uma falha sinistral que deslocou uma parte da intrusão por cerca de 9 Km (GASTAL; NARDI, 1992), o que pode ser claramente demonstrado pela interpretação de imagens de satélite (Fig. 7B).

Outro potencial importante desse alto topográfico seria constituir um divisor de águas entre três importantes bacias gaúchas: a bacia do rio Santa Maria (afluente do rio Ibicuí) a oeste; a bacia hidrográfica do rio Camaquã a leste; e a bacia do rio Vacacaí (afluente do rio Jacuí) a norte. Por esse motivo, foi implantado no local um marco comemorativo, o 'marco gaúcho das águas'. A área de Lagoa da Meia-Lua/Palma é distante de qualquer centro urbano, estando a $30 \mathrm{Km}$ da cidade de Lavras do Sul, com acesso exclusivamente por estradas não asfaltadas, o que pode constituir entrave a um aproveitamento geoturístico mais significativo. Considerando seu isolamento e pouca visitação, não é recomendada aqui, para este momento, qualquer implantação de painéis interpretativos ou outros equipamentos.

Figura 7: Panorama de uma das porções do maciço granítico (A) da área da Meia-Lua/Palma, em Lavras do Sul (B) imagem de satélite apontando o deslocamento de uma porção do Granito Jaguari ao longo da Falha Cerro dos Cabritos, de orientação NE-SW.

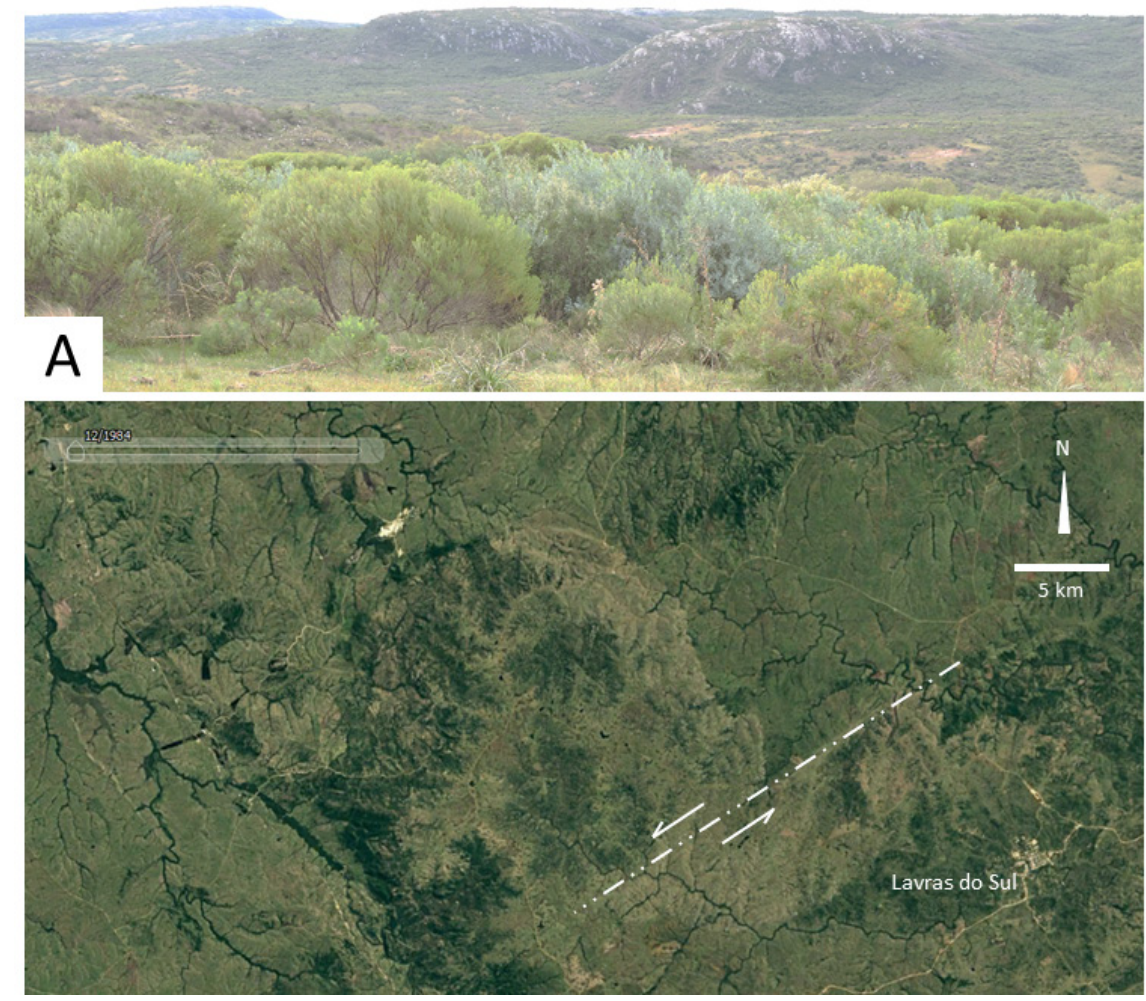

Fonte: fotos e preparação da imagem pelos autores. 


\section{Pedras das Guaritas}

A porção sul do município de Caçapava do Sul, já nos domínios da bacia hidrográfica do rio Camaquã, no limite com Bagé, possui certamente o mais importante atrativo geoturístico do COREDE Campanha: a área chamada de Pedras das Guaritas (ponto 6 da Fig. 3), considerada uma das sete 'maravilhas turísticas' do Rio Grande do Sul em uma pesquisa realizada pela Secretaria Estadual do Turismo, ainda na década de 1990. Sua porção mais característica, com cerca de $30 \mathrm{~km}^{2}$ de área, constitui-se de uma série de cerros ruiniformes com formatos irregulares e pitorescos (Fig. 8A), semelhantes a torres, casamatas ou guaritas de vigilância, característica geomorfológica que deu nome à região.

Esses cerros se desenvolveram por alteração e erosão diferencial de camadas de rochas sedimentares de diferentes granulometrias e porosidades, pertencentes à unidade estratigráfica Guaritas. São arenitos com estratificações cruzadas, arenitos com níveis de seixos, siltitos e conglomerados, sempre de coloração avermelhada e com fragmentos bem arredondados (Fig. 8B), características que denotam sedimentação fluvial há cerca de 500 Ma. Fraturas, marmitas e panelas, entre outras feições de dissolução e erosão hídrica e eólica, completam sua substancial geodiversidade, que ensejou a inscrição desse geomonumento na lista da Comissão Brasileira de Sítios Geológicos e Paleobiológicos (SIGEP), que reconhece o geopatrimônio brasileiro, sob a designação de Guaritas do Camaquã (PAIM; FALLGATER; SIVEIRA, 2010).

Além de sua relevância geológico-geomorfológica, as Pedras das Guaritas se destacam no valor ecológico, por abrigarem flora endêmica composta por cactos e bromélias e fauna ameaçada de extinção (BORBA et al., 2016), e também por valor estético, já que sua beleza cênica tem chamado a atenção como cenário para produções cinematográficas e televisivas (BORBA et al., 2013), como o filme Valsa para Bruno Stein de 2007, e a série Animal, de 2014, ambos dirigidos por Paulo Nascimento. A paisagem local ainda possui uma característica cultural relevante: é o espaço de vida e reprodução social de uma população tradicional do pampa serrano, a dos pecuaristas familiares (SOUZA, 2018), criadores sobretudo de pequenos animais, como ovelhas e cabras (Fig. 8C).

A área já possui uma visitação consistente ao longo do ano, ainda que desconhecida e sem controle (em termos de número e perfil de turistas) principalmente para trilhas pedestres e contemplação da paisagem. Mesmo sendo um geomonumento distante (cerca de $54 \mathrm{~km}$ ) da sede municipal, a maior parte desse trajeto é feito por rodovias asfaltadas e, de maneira geral, o trecho não pavimentado é largo, regular e de boa trafegabilidade (10 km pela RS-625, a 'estrada velha da mina'). Um melhor aproveitamento geoturístico das Pedras das Guaritas poderia ser obtido com uma estruturação da sede da Associação de Moradores das Guaritas, uma demarcação adequada de suas trilhas e a instalação de painéis interpretativos, bem como com a implantação de miradores na RS-625, conforme sugerido já por Sell (2017) e Sell e Borba (2018).

Cerca de $12 \mathrm{~km}$ a oeste do geomonumento das Pedras das Guaritas, encontra-se a vila de Minas do Camaquã, uma company-town construída no auge da mineração de cobre 
pela Companhia Brasileira do Cobre (CBC) e Grupo Pignatari, atualmente em estado de parcial abandono. Além de um rico patrimônio geomineiro (DOMINGUES, 2016; VON AHN; URBAN; SIMON, 2017; VON AHN; SIMON, 2017), material e imaterial, que merece valorização e interpretação (BORBA et al., parte II, neste número), a vila conta desde 2013 com um empreendimento de esportes de aventura na natureza, onde a tirolesa, o arvorismo e a canoagem são destaques. O geoturismo no local, que complementaria a visitação às Pedras das Guaritas, poderia se beneficiar de um acesso mais seguro e garantido às antigas galerias subterrâneas de extração de minério. Porém atingir esse objetivo demanda uma negociação complexa, além de substanciais ajustes em termos de segurança pessoal para os turistas.

O mesmo contexto geopatrimonial das Pedras das Guaritas é observado na extensa área das Pedras das Torrinhas (ponto 9 da Fig. 3), situada no extremo leste do município de Bagé, nos limites do COREDE Campanha com o município de Pinheiro Machado. São depósitos dominantemente aluviais da unidade Guaritas, do início do Cambriano (MARCONATO et al., 2009). No entanto, essa área tem uma acessibilidade muito complicada, seja a partir da BR-153 (por Bagé), seja a partir da BR-293 (por Candiota), por longas distâncias em estradas não-pavimentadas, com trechos sempre maiores a $30 \mathrm{~km}$. Assim, a área fica prejudicada para um potencial aproveitamento turístico, sendo desconsiderada neste momento para tal fim. No entanto, é importante fazer um alerta do ponto de vista da geoconservação de que a região das Pedras das Torrinhas já possui, em seu entorno, talhões de silvicultura de espécies exóticas (Fig. 8D), que podem provocar ocultação e degradação dos (ainda pouco conhecidos) ecossistemas e organismos ali abrigados. 
Figura 8: Aspectos dos geomonumentos Pedras das Guaritas e Pedras das Torrinhas: (A) perfil de cerros ruiniformes das Pedras das Guaritas; (B) arenitos conglomeráticos avermelhados, com seixos e blocos arredondados, formados em ambiente fluvial; (C) rebanho de cabras sobre uma das elevações das Pedras das Guaritas, com uma janela de erosão hídrica/eólica; (D) proximidade entre geoformas ruiniformes (setas verticais brancas) e talhões de silvicultura (manchas escuras) na área das Pedras das Torrinhas, no limite entre Bagé e Pinheiro Machado.
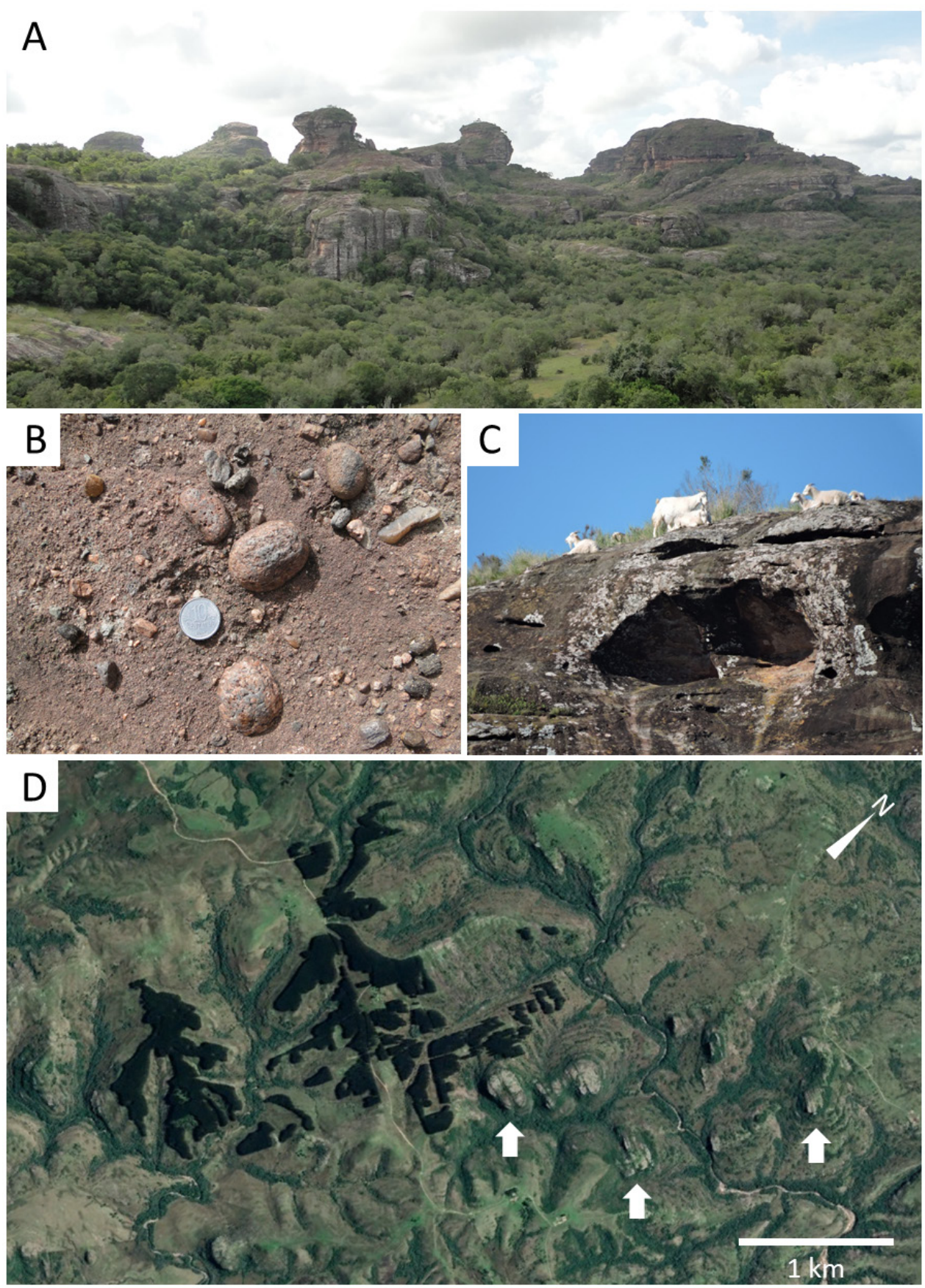

Fonte: fotos e preparação da imagem pelos autores. 
O Rincão do Inferno (ponto 7 da Fig. 3), conhecido também pelos habitantes locais como Rincão dos Franco, situa-se no limite entre os municípios de Bagé e Lavras do Sul. Constitui-se por um maciço de aproximadamente $3 \mathrm{~km}^{2}$ formado por rochas sedimentares (de posição estratigráfica duvidosa, mas certamente entre 590 e $500 \mathrm{Ma}$, no contexto da Bacia do Camaquã), levemente basculadas e muito resistentes ao intemperismo. São conglomerados aluviais/fluviais com proveniência sobretudo granítica. O grande destaque geológico-geomorfológico dessa área é a presença de uma estrutura tectônica vertical, que corta o maciço na direção NE-SW por cerca de 1,5 km (Fig. 9A), e que encaixa, em seu interior, o rio Camaquã, com seus bancos arenosos e grandes blocos de rocha caídos (Fig. 9B).

Além do aspecto geológico-geomorfológico, que impacta nos valores ecológico e estético, o grande potencial do Rincão do Inferno é, na verdade, relacionado à cultura e história. A área comporta um remanescente quilombola, com casas baixas construídas de pau-a-pique (Fig. 9C), onde reside a família Franco, que empresta o nome alternativo à área. O quilombo das Palmas, onde essa área se insere, abriga cerca de 30 a 40 famílias, ligadas por um vínculo comum de ancestralidade (KOSBY, 2016 apud ISMÉRIO et al., 2017). A utilização de cânions (ou rincões, no linguajar local), como o Rincão do Inferno e outras áreas declivosas, para esconderijo e resistência contra tentativas de recaptura dos escravos fugidos foi discutida preliminarmente por Borba et al. (2014), e merece maior reflexão e estudos mais aprofundados. A área também é muito utilizada para a prática de esportes de aventura, como a canoagem em caiaques e o psico-bloc (Fig. 9D), uma modalidade de bouldering realizada junto à água.

O Rincão do Inferno é um geomonumento desprovido de visibilidade a partir de rodovias, e muito distante tanto de Bagé $(92 \mathrm{~km})$ quanto de Caçapava do Sul $(71 \mathrm{~km})$. No entanto, a maior parte do trajeto até o geomonumento se dá em rodovia asfaltada (a BR-153), com cerca de $11 \mathrm{~km}$ de estradas não-pavimentadas e uma curta trilha pedestre ao final. Por isso, e especialmente por sua singularidade de encaixar o trecho inicial de um dos principais rios do Estado, recomenda-se aqui uma atenção especial por parte do poder público a esse geomonumento, cujo acesso por Lavras do Sul é difícil e desencorajado pelos proprietários locais, e cujo acesso por Bagé é, por vezes, interrompido pelos fazendeiros dos terrenos adjacentes ao remanescente quilombola. O potencial da área está especialmente vinculado à contemplação da paisagem, à presença de água e à prática de esportes de aventura, e fica ainda mais interessante quando integrado ao geomonumento Casa de Pedra ou Pico do Morcego, conforme detalhado a seguir. 
Figura 9: Aspectos geopatrimoniais do Rincão do Inferno, entre Bagé e Lavras do Sul: (A) visão geral do maciço e da estrutura tectônica aproximadamente retilínea na qual o rio Camaquã se encaixa; (B) panorama interno ao cânion em época de estiagem, com seus bancos de areia, paredões íngremes e grandes blocos caídos no leito do rio; (C) casa de pau-a-pique, pertencente a remanescente de comunidade quilombola; (D) montanhista praticando psico-bloc no interior do Rincão do Inferno.

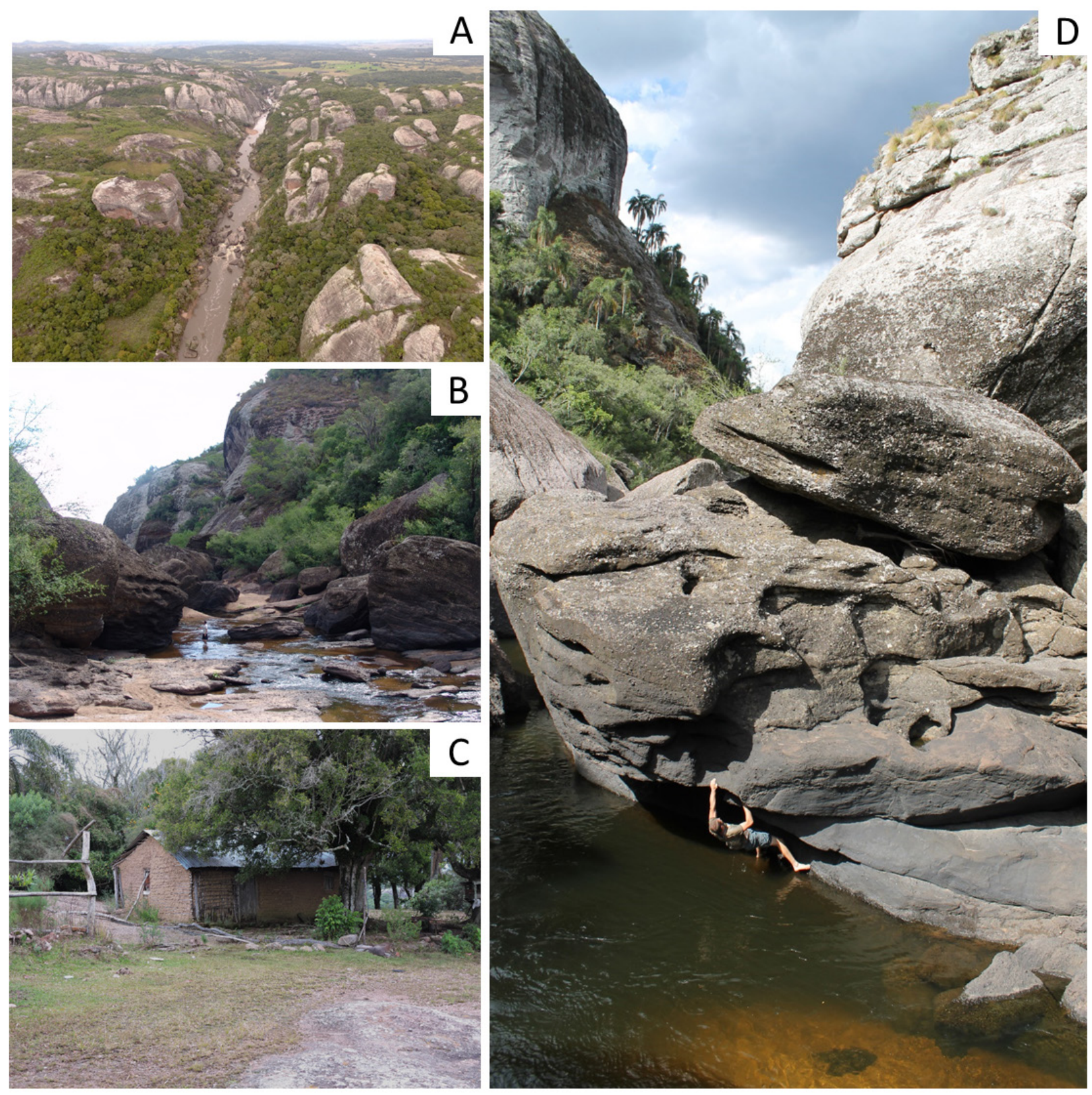

Fontes: (A, C) fotos obtidas pelos autores; (B) foto obtida por Luiz Fernando de Souza; (C) foto obtida por Paola Prates Stumpf.

Casa de Pedra ou Pico do Morcego

O geomonumento Casa de Pedra (ponto 8 na Fig. 3), ao contrário do Rincão do Inferno, é um maciço de substancial visibilidade a partir da rodovia BR-153, de onde se 
observa seu perfil pitoresco (Fig. 10A). Por seu elevado valor estético, com um perfil irregular e diversas cores e texturas de rocha exposta, um ponto naquela rodovia foi, inclusive, considerado para implantação de um mirador de observação da paisagem nos trabalhos de Sell (2017) e Sell e Borba (2018). Totalmente inserido no município de Bagé, entre os arroios Lechiguana e Catarina, afluentes do rio Camaquã, o acesso ao geomonumento se dá pela BR-153, por cerca de $60 \mathrm{~km}$ no sentido norte desde a zona urbana daquele município, seguindo por estradas vicinais não pavimentadas $(12 \mathrm{~km})$ posicionadas a leste da rodovia.

Do ponto de vista geológico, o maciço é formado por conglomerados aluviais, de idade incerta, possivelmente relacionadas às unidades Bom Jardim ou Santa Bárbara (590 a $540 \mathrm{Ma}$ ), com seixos de rochas ígneas muito ricas em feldspatos potássicos, o que confere uma coloração avermelhada às porções sem alteração. Essas rochas foram desenhadas pelos agentes do clima, formando um conjunto de formas arredondadas, cravejadas de janelas de erosão hídrica/eólica (Fig. 10B). Um grande bloco de $2.800 \mathrm{~m}^{2}$ de área em planta e mais de 30 metros de espessura desprendeu-se do maciço principal, deixando embaixo de si um espaço vazio (Fig. 10C), na forma de um abrigo (ou 'casa de pedra'), que dá o nome do conjunto de geoformas. Esse abrigo já foi utilizado em produções cinematográficas, como no recente filme $O$ tempo e o vento (2013), de Jaime Monjardim. As dimensões desse abrigo, assim como seus valores educativo e cultural, permitem que outros abrigos menores, como a Toca das Carretas e a Gruta da Varzinha sejam considerados como de abrangência apenas municipal, e não para a escala do COREDE Campanha.

O grande potencial do geomonumento Casa de Pedra, no entanto, está em sua utilização para a prática da escalada em rocha. Os montanhistas dividem o maciço rochoso em uma série de setores: (a) o Conjunto Principal, com 13 vias de escalada; (b) o setor Marimbondo, com 14 vias; (c) o Pico do Morcego (Fig. 10D, 10E), que é a protuberância rochosa isolada do conjunto, e que também constitui um dos nomes utilizados para o geomonumento, com 5 vias; (d) o Ninho das Águias, com 2 vias; o setor Casa de Pedra, no bloco colapsado que formou o abrigo natural, com 3 vias; o setor Sabão de Coco, com 7 vias; entre outros setores menos frequentados. Muitas dessas vias são de grande dificuldade, chegando aos graus 8 e 9 na escala brasileira de graduação de vias de escalada, o que torna o geomonumento um atrativo muito procurado por esses esportistas. Recomenda-se aqui que a interpretação geopatrimonial possa ser integrada a esses programas, já neste momento com painéis interpretativos, no sentido da divulgação de seus aspectos de geodiversidade. Para o futuro, deve-se incluir na estratégia a implantação de um mirador na BR-153, conforme recomendados por Sell (2017), o que só poderá ser alcançado após negociação com o DNIT. 
Figura 10: Atributos da Casa de Pedra (Pico do Morcego), em Bagé: (A) perfil irregular do maciço rochoso de conglomerados; (B) janelas de erosão hídrica/eólica nas paredes verticais; (C) abrigo natural formado por colapso gravitacional de um dos blocos, que constitui a Casa de Pedra em si; (D) croqui das vias de escalada já implantadas no setor Pico do Morcego e (E) pico isolado do conjunto principal.
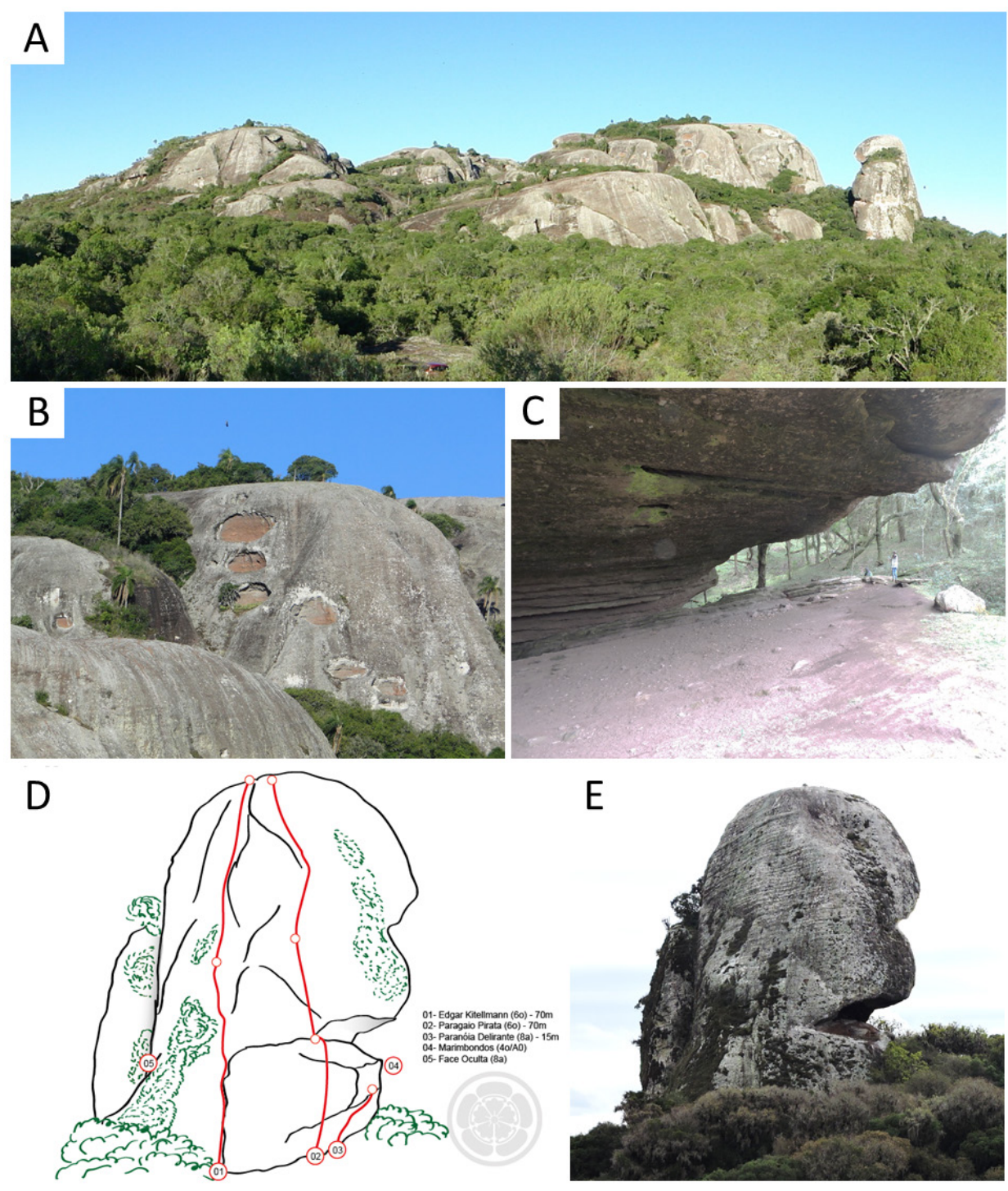

Fontes: (A, B, C, E) fotos obtidas pelos autores; (D) croqui elaborado pelo escalador Naoki Arima (naokiarima. com.br/croquiteca/rs/bage-rs).

\section{Platô do Taquarembó}

O arroio Taquarembó marca, no chamado Passo dos Guterres o limite entre os municípios de Lavras do Sul, a norte, e Dom Pedrito, a sul. Esse curso d'água corta uma feição geomorfológica relativamente alta e plana, com algumas bordas de declividade acentuada, conhecida no meio acadêmico de geociências como o Platô do Taquarembó (SOMMER; LIMA; NARDI, 1999), marcado no ponto 11 da Fig. 3. Essa feição tem como substrato as mesmas rochas vulcânicas ácidas da Serra de Santa Bárbara e do platô da Ramada, da 
unidade estratigráfica Acampamento Velho (570 Ma), formadas por eventos de derrames de lavas andesíticas, riolíticas e por explosões piroclásticas formadoras de ignimbritos.

Além de pequenos cânions e áreas com lajeados de riolitos ao longo do trajeto do arroio, que se traduzem em um elevado valor estético, a porção norte do platô, na área chamada Curral de Pedra, em Lavras do Sul, possui feições lineares e circulares de dissolução (um relevo cárstico não-convencional, não-carbonático) que abrigam inúmeros banhados, pequenos lagos e outras áreas de solos hidromórficos, em meio a afloramentos rochosos. Isso eleva o valor ecológico do geomonumento. Outro potencial refere-se à construção de uma barragem em concreto para armazenamento de água para irrigação, a Barragem do Taquarembó (iniciada em 2009 e interrompida até o momento). Quando estiver concluída, formará um lago onde poderão ser praticados esportes aquáticos e para balneário. O Passo dos Guterres, local onde uma estrada vicinal cruza o arroio Taquarembó, fica a apenas 18 km da sede municipal de Dom Pedrito e, portanto, da BR-293, o que facilita o acesso ao local.

\section{CONSIDERAÇÕES FINAIS}

A área de abrangência do COREDE Campanha possui um significativo potencial para o geoturismo, sobretudo em suas áreas complexas, de grande importância geocientífica e ecológica. A beleza cênica dessas áreas, juntamente com sua vocação natural para os esportes de aventura na natureza, são fatores de alta atratividade turística para públicos diversificados e qualificados, aptos a receberem interpretação geopatrimonial em seus programas turísticos. Espera-se que o presente levantamento seja o primeiro passo para uma série de outras pesquisas e iniciativas concretas, que devem incluir: (1) um progressivo e necessário detalhamento, em escala compatível, de cada um dos geomonumentos inventariados, inclusive sobre sua capacidade de carga e sobre os impactos ambientais preexistentes; (2) uma estratégia, de responsabilidade do COREDE Campanha, em parceria com os municípios e com outras instituições públicas e privadas, para dotar os geomonumentos aqui indicados com infraestrutura mínima necessária à recepção qualificada de turistas; e (3) o incremento, a partir de conhecimento e infraestrutura, da oferta turística voltada a esses conteúdos, de alta relevância no cenário atual de valorização da geodiversidade e do geoturismo.

\section{REFERÊNCIAS}

ALDRIDGE, Don. Mejora de la Interpretación de los Parques y la Comunicación con el Público. UICN (ed.). Segunda Conferencia Mundial sobre Parques Nacionales. Yellowstone y Grand Teton, 1973. p. 18-27 (Informe, 25).

ALMEIDA, Delia del Pilar Montecinos de; CONCEIÇÃO, Rômulo Vieira; CHEMALE Jr., Farid et al. Evolution of heterogeneous mantle in the Acampamento Velho and Rodeio Velho volcanic events, Camaquã Basin, Southern Brazil. Gondwana Research, v. 8, n. 4, p. 479-492, 2005.

BORBA, André Weissheimer de. Geodiversidade e geopatrimônio como bases para estratégias de geoconservação: conceitos, abordagens, métodos de avaliação e aplicabilidade no contexto do Estado do Rio Grande do Sul. Pesquisas em Geociências, v. 38, n. 1, p. 3-13, 2011. 
Um geopark na região de Caçapava do Sul (RS, Brasil): uma discussão sobre viabilidade e abrangência territorial. Geographia Meridionalis, v. 3, n. 1, p. 104-133, 2017.

; SELL, Jaciele Carine. Uma reflexão crítica sobre os conceitos e práticas da geoconservação. Geographia Meridionalis, v. 4, n. 1, p. 2-28, 2018.

et al. Inventário e avaliação quantitativa de geossítios: exemplo de aplicação ao patrimônio geológico do município de Caçapava do Sul (RS, Brasil). Pesquisas em Geociências, v. 40, n. 3, p. 275-294, 2013.

; SELL, Jaciele Carine; FIGUEIRÓ, Adriano Severo. Dimensão cultural da geodiversidade e do geopatrimônio de Caçapava do Sul, Rio Grande do Sul, Brasil. In: ENCONTRO LUSO-BRASILEIRO DE PATRIMÔNIO GEOMORFOLÓGICO E GEOCONSERVAÇÃO, 1, 2014, Coimbra. CD de Resumos.

; SILVA, Elisângela Lopes da; SOUZA, Luiz Paulo Martins; SOUZA, Luiz Fernando de; MARQUES, Rosane Vera. Relação entre a geodiversidade intrínseca e a estruturação de habitat na escala do geossítio: exemplos na Serra do Segredo e nas Pedras das Guaritas (Caçapava do Sul, RS, Brasil). Pesquisas em Geociências, v. 43, n. 2, p. 183-202, 2016.

BRILHA, José Bernardo Rodrigues. Património geológico e geoconservação: a conservação da natureza na sua vertente geológica. Viseu: Palimage Editores, 2005.

CARGNIN, Antonio Paulo. Políticas de desenvolvimento regional no Rio Grande do Sul: vestígios, marcas e repercussões territoriais. Porto Alegre, 2011.Tese de (Doutorado em Geografia), Universidade Federal do Rio Grande do Sul, UFRGS.

CORIOLANO, Luzia Neide Menezes Teixeira. A contribuição do turismo ao desenvolvimento local. In: PORTUGUEZ, Anderson Pereira; SEABRA, Giovanni de Farias; QUEIROZ, Odaléia Telles M. M. (Orgs.) Turismo, Espaço e Estratégias de Desenvolvimento local. João Pessoa: Ed. UFPB, 2012.

DE BIASI, Mário. A carta clinográfica: os métodos de representação e sua confecção. Revista do Departamento de Geografia, v. 6, p. 45-60, 1992.

DEGRANDI, Simone Marafiga. Ecoturismo e interpretação da paisagem no Alto Camaquã/RS: uma alternativa para o (des)envolvimento local. Santa Maria, 2011. Dissertação (Mestrado em Geografia), Universidade Federal de Santa Maria, UFSM.

DOMINGUES, Silvio Avila. Patrimônio geo-mineiro da localidade de Minas do Camaquã (Caçapava do Sul, RS). Santa Maria, 2016. Dissertação (Mestrado em Geografia), Universidade Federal de Santa Maria, UFSM.

FASSOULAS, Charalambos; MOURIKI, Dimitra; DIMITRIOU-NIKOLAKIS, Panagiotis; ILIOPOULOS, George. Quantitative assessment of geotopes as an effective tool for geoheritage management. Geoheritage, v. 4, n. 3, p. 177-193, 2012.

FUERTES-GUTIÉRREZ, Inés; FERNÁNDEZ-MARTÍNEZ, Esperanza. Geosites inventory in the Leon Province (Northwestern Spain): a tool to introduce geoheritage into regional environmental management. Geoheritage, v. 2, p. 57-75, 2010.

GASTAL, Maria do Carmo Pinto; LAFON, Jean Michel. Gênese e evolução dos granitóides metaluminosos de afinidade alcalina da porção oeste do Escudo Sul-riograndense: geoquímica e isótopos de $\mathrm{Rb}-\mathrm{Sr}$ e $\mathrm{Pb}-\mathrm{Pb}$. Revista Brasileira de Geociências, v. 28, n. 1, p. 11-28, 1998.

GASTAL, Maria do Carmo Pinto; NARDI, Lauro Valentim Stoll. Petrogênese e evolução do Granito Jaguari: um típico representante metaluminoso da Suíte Intrusiva Alcalina Saibro, RS. Geochimica Brasiliensis, v. 6, n. 2, p. 169-189, 1992.

GRAY, Murray. Geodiversity: valuing and conserving abiotic nature. Chichester: Wiley, 2004.

HASENACK, Heinrich; WEBER, Eliseu. Base cartográfica vetorial contínua do Rio Grande do Sul - escala 1:50.000. Porto Alegre: UFRGS Centro de Ecologia. 2010. DVD-ROM. (Geoprocessamento, 3).

HENRIQUES, Maria Helena; PENA-DOS-REIS, Rui; BRILHA, José Bernardo Rodrigues; MOTA, Teresa. Geoconservation as an emerging geoscience. Geoheritage, v. 3, n. 2, p. 117-128, 2011.

HOSE, Thomas A. Selling the story of Britain's stone. Environmental Interpretation, v. 2, p. 16-17, 1995. 
ISMÉRIO, Clarisse; CAPELLARI, Lize Helena; CARRETTA, Ângela Jagmin; DRUMM, Elisabeth. Rincão do Inferno: patrimônio geoambiental e cultural situado às margens do rio Camaquã. Confins, v. 31, 2017. Disponível em: http://journals.openedition.org/confins/12086 Acesso em: 26 out. 2018.

MARCONATO, André; ALMEIDA, Renato Paes de; SANTOS, Maurício G.M. et al. Alluvial-eolian interaction in a Cambrian rift margin: the Pedra das Torrinhas and Pedra Pintada formations (Guaritas Group, RS). Anais da Academia Brasileira de Ciências, v. 81, n. 4, p. 819-836, 2009.

PAIM, Paulo Sérgio Gomes; FALLGATER, Claus; SILVEIRA, Ariane Santos da. Guaritas do Camaquã, RS: exuberante cenário com formações geológicas de grande interesse didático e turístico. In: WINGE, M. et al. (Eds.) Sítios geológicos e paleontológicos do Brasil, 2010. Disponível em: www.unb.br/ig/sigep/ sitio076/ sitio076.pdf Acesso em: 30 out. 2018.

PEIXOTO, Carlos Augusto Brasil. Geoparque Guaritas - Minas do Camaquã (Proposta). Porto Alegre: CPRM, 2017.

RISK, Paul H. The Interpretive Talk. In SHARPE, G. (ed.). Interpreting the Environment. London: Wiley \& Sons, 1982.

SANTOS, Fabio Castilhos Arruda dos. Mapeamento geomorfológico do Geossítio das Guaritas do Camaquã/RS: subsídios à geoconservação. Pelotas, 2016. Dissertação (Mestrado em Geografia), Universidade Federal de Pelotas, UFPel.

SELL, Jaciele Carine. Estradas paisagísticas: estratégia de promoção e conservação do patrimônio paisagístico do Pampa Brasil-Uruguai. Santa Maria, 2017. Tese (Doutorado em Geografia), Universidade Federal de Santa Maria, UFSM.

; BORBA, André Weissheimer de. Um roteiro geoturístico na estrada paisagística Guaritas (Santana da Boa Vista e Caçapava do Sul, RS, Brasil). Terr@ Plural, v. 12, n. 3, p. 320-331, 2018.

SILVA. Elisângela Lopes da. Proteção do patrimônio natural da Serra do Segredo (Caçapava do Sul, RS, Brasil): um diálogo entre a geoconservação e o Sistema Nacional de Unidades de Conservação (SNUC). Santa Maria, 2016. Dissertação (Mestrado em geografia), Universidade Federal de Santa Maria, UFSM.

SOLIANI JUNIOR, Enio. Os dados geocronológicos do Escudo Sul-rio-grandense e suas implicações de ordem geotectônica. São Paulo, 1986. Tese (Doutorado em Geologia), Universidade de São Paulo, USP.

SOMMER, Carlos Augusto; LIMA, Evandro Fernandes de; NARDI, Lauro Valentim Stoll. Evolução do vulcanismo alcalino da porção sul do Platô do Taquarembó, Dom Pedrito-RS. Revista Brasileira de Geociências, v. 29, n. 2, p. 245-254, 1999.

SOUZA, Luiz Paulo Martins e. Tradição e transformação no pampa serrano das Guaritas do Camaquã: um estudo de percepção da paisagem. Santa Maria, 2018. Dissertação (Mestrado em Geografia), Universidade Federal de Santa Maria, UFSM.

TILDEN, Freeman. Interpreting our heritage. Chapell Hill: The University of North Carolina Press, 1957.

TOURTELLOT, Jonathan B. Geotourism for your community: a guide for a geotourism strategy. Washington (DC): National Geographic Society, 2006.

VON AHN, Maurício Mendes; URBAN, Camile; SIMON, Adriano Luís Heck. Diagnóstico Ambiental da Área de Proteção do Geossítio Minas do Camaquã-Rio Grande do Sul-Brasil (Environmental diagnosis of the protection area of the Minas do Camaquã Geosite-Rio Grande do Sul state-Brazil). Revista Brasileira de Geografia Física, v. 10, n. 4, p. 1254-1268, 2017.

VON AHN, Maurício Mendes; SIMON, Adriano Luís Heck. Geomorphological mapping and geodiversity: study at the Minas do Camaquã geosite protection area (Brazil). Revista Brasileira de Geomorfologia, v. 18, n. 2, 2017.

Data de submissão: 10/ abr./ 2019

Data de aceite: 26/ ago./ 2019 